\title{
BEST PRACTICE: A VIDEO MEDIATED TEACHING OF PHONOLOGY
}

\author{
Drs. Musta'in, M.Pd. \\ Universitas Islam Kadiri \\ mustain@fkipuniska.ac.id \\ Wildan Isna Asyhar, M.Pd. \\ Universitas Islam Kadiri \\ wildan@fkipuniska.ac.id
}

\begin{abstract}
A narrative inquiry as the approach of qualitative research is conducted in this research to know how the implementation of a video as a teaching media of Phonology and what the problems that the students face in using a video as the learning media of Phonology. This research involves 28 students of the second grade. The subject of research is the students of an English department in Education of UNISKA Kediri. The result is that there are four categorized problems that students face. Students felt that; (1) a native speaker in the video speaks too fast; (2) the pronunciation is unclear; (3) there are some new words or terms; (4) it is difficult to imitate the intonation and stressing of a word and sentence. However, the students can solve problems. Besides that, they get some advantages their ability in some aspects and are aware of the current issue; (1) the first is that the video is easy accessible; (2) the second one is that the video also is appropriate with the current issue so the students, beside learn about phonology, also aware of the current issue; (3) the other one is the students can learn and practice whenever with (out) the guidance of the lecturer; (4) the last advantage that we can offer is the students can listen the native speaker easily because they can play back the video when they cannot catch the word or meaning.
\end{abstract}

Keywords: a video, teaching, a phonology

\section{INTRODUCTION}

The high tension of global competition has insisted society across the world to be capable of speaking another foreign language in order to widen their communication target. In line with Kanno \& Varghese (2010) states (2010) that promoting communication is the prior goal of a language. Considering that demand of rapid worldwide connection, a language must be standardized as an international language due to the language diversity belonged to each country. English has firmly been acknowledged as the most important and influential universal language. English spreading is much more globally admitted than other spoken languages 
even though England does not have the biggest number of native speakers. In the year 2000, Mandarin speaks by approximately 874 million native speaker; Hindi, 366 million; and English, 341 million. Besides 341 million native speakers, there are 150 to 300 million people who deliver English as a second language and 100 to 1000 million speakers using it as a foreign language. (Crystal,1997). English also dominates the means of both the most official written and spoken information globally. Crystal (2000) stated that $85 \%$ of worldwide organizations set up their official administration in English nowadays. Those facts lead learning English to be a subject which is obligated in most countries in the world including Indonesia which has active participation in global trading.

Simatupang (1999:66-69) asserted that the number of various parent speeches consisting of local dialogues such as Javanese, Batak or Balinese has led Indonesian to speak English in less effective way. English learners in Indonesia do not only rely on schools which provide English teaching but also the studying sources that they find out independently, so to minimize the matter of mother tongues they should deal with, most of the learners are expected to speak in similar ability of a native speaker. In short, having a standard of learning English will eliminate the obstacles of the learners.

In Indonesia, as an English foreign learner expects to have the native speaker's ability to look like. The target of building foreign language skill using native speaking ability as standard makes more subjects of language are researched to find the proper pattern of study. Many studies found out that foreign language learners should learn linguistics defining as a language study to master a language. As Wilkin (1972: 229) confirms that linguistics has shown a significant contribution to gain students' nature of language understanding. It is in line with Pit Corder (1973:30). He states that the part of linguistics is to offer the most detailed and exhaustive view of language. It is obviously clear that studying linguistics gives deeper insights to master foreign language especially English. Linguistics consists of seven fundamental study features: language form, language meaning and pragmatic context (language context), semantics (meaning), syntax (sentence structure), morphology (word structure), phonology (sound pattern), and phonetics (speech sound production, acoustics and hearing). 


\section{Phonology as the Target Language}

Phonology is one of linguistics aspects which are often ignored during the language learning due to the prioritizing of semantics, syntax, and morphology. However, the foreign language learners face some learning difficulties from several sides, including pronouncing the foreign words. Lanteigne (2006) affirms that the absence of some English sounds in learners' local language has surely participated in their difficulties of learning English. Odden (2006) links pronunciation to phonology as the base part of linguistics that scientifically studies about the language structure. Phonology explains various aspects for instance kinds of language sound, the word sound combination, and the importance of certain phonetic features in a word identification (University of Sheffield 2012). These various aspects cause the learners face problems in identifying and producing the foreign sounds. The foreign sounds involve not only sounds in isolation but also sounds occurring in a connected speech. The learners should be able to join each sound in a sequence to the next sound without difficulty. The familiarity with phonetic symbols is very important since they represent more consistently than letters. Another problem is concerning with the production of supra-segmental features like stress, length, pitch, and intonation. Ramelan (2003) adds that the speech organs of foreign language learners have been set to produce the speech sounds of their own language. It makes them difficult to change their speech organs in producing the foreign sounds. It is clear that learning problems encountered by foreign language learner are caused by differences between learner's language and the target language. These differences may be in the individual sounds, in the phonetic features of similar sounds, and the distribution of equivalent sounds. Through imitation, much practice, and repetition, however, the learner will succeed in producing the foreign sound correctly in the same way as the native speaker. To deal with the issues, studying phonology is considered to maintain students in better pronunciation.

Students who have learned phonology are expected to actively communicate using well-pronounced vocabularies although those words do not exist in their mother tongue. They will be able to articulate accurately some sound variations 
appearing in their foreign language speaking as students are targeted to speak as natives.

\section{Behaviorism}

Among the studies conducted on language learning involves the perspectives of the learners themselves (Carson, 2004; Fong, 2005; Narayanan et al., 2008; Matsuzaki, 2006). After considering more aspects that come up to build up English ability such as phonology and phonetics, the learners have turned to be a research object to gain the appropriate language teaching and learning methods for them. Some studies conducted examine the language experience and perspective of the students. Indeed, taking into consideration the learners' perspective is a useful tool to understand the factors that contribute to effective language learning (Matsuda, 2004; Matsumoto, 1996). Involving the students in the research will provide more considerations in arranging effective strategies for teachers and students in learning language process.

Language learning systematically consists of four significant studies and close theories of language acquisition and learning; behaviorism, cognitivism, humanism, and constructivism (Fauziati, 2016). From those theories, behaviorism is regarded as the foundation of effective learning strategies. Behaviorism presents the change of students' behavior as the sign of successful learning. Therefore, students who have learned the lesson well are considered to act differently to create a new positive habit as the learning result. Skinner (1976) affirms that learning is an accustoming process of adaptation using both simulation and understanding in the fundamental parts of cognition stimulation. It means language learners are given a stimulus in several ways to get them adapted in new behavior leading to language mastery. Drilling and imitating are techniques which are often taken to do language learning conditioning, yet those still need support of teaching and learning media in order to boost the target. Media of teaching and learning can be various depending on the needs and situation also condition especially from students. 


\section{Video as Teaching/Learning Media}

A number of studies approves that an instructional media can create an amusing collaboration among teachers and students since it will facilitate the learning process well. Scanlan (2004) defines instructional media as all instruments which the teachers use to teach and help students in achieving instructional assessment. A media required is surely developed based on the needs of today's learners which actively use technology in their daily base. More teaching media is designed using technology to create an active and innovative learning.

The media frequently used nowadays is moving images or what is usually called as video. The creative challenge of using moving images and sound to communicate a topic indeed engaging and insightful, but adds that it also enables students to acquire a range of transferable skills in addition to filmmaking itself (Allam, 2006). Video as a teaching and learning media provides a clear and interesting presentation of any teaching materials. It portrays the information for the students through illustrations of real condition which can help the students to relate easily. By utilizing a video in teaching, many concepts and descriptions can be learnt clearly and interestingly; in addition, it helps students to achieve cognitive, psychomotor, and affective goals in the learning process (Putri, Titin, \& Santoso, 2019).

In this research, the researchers, therefore, want to know the application of the technique to the students of UNISKA in using a video as a teaching media to teaching phonology. This research is necessary a direct observation to know how this technique works in UNISKA Kediri for one semester. Based on the introduction and the aim of the research above, the researchers take the research entitle "Best Practice: a Video Mediated Teaching of Phonology”.

\section{RESEARCH METHODOLOGY}

Like as the background of the study above, the lecturer uses some techniques in the media. The video is the media selected to engage the students in the teaching and 
learning process. The researchers want to identify with the following research questions:

1. How is video used for students to teach phonology?

2. What kinds of problems are faced by students when using the video?

A qualitative method is selected in this research because the researchers want to know the issue in depth with data collection. It is in line with Patton (2002) who states that qualitative methods allow the researcher to study issues in depth with data collection often occurring through open-ended questions permitting "one to understand and capture the points of view of other people without predetermining those points of view through prior selection of questionnaire categories". Based on approaches of qualitative, at least 5 kinds of qualitative research; ethnography, grounded theory, narrative, case study, and phenomenology.

Here, the researchers use narrative inquiry as the approach of qualitative research. Bleakley (as cited in Michelle, 2015:190) stated that Narrative research is a part of qualitative research where the stories of the researcher become the rude data. In this research the main data is the story of the researcher as the participant in the research also, although, interview and document exist. It makes the data have deep understanding because the researchers apply triangulation. In line with Patton (1999) declares that triangulation refers to the use of multiple methods or data sources in qualitative research to develop a comprehensive understanding of phenomena.

The use of story telling method is to present the data collection in this study in which the data is from the students of semester 4. Moreover, 28 students were involved in this research. It was done during pandemic of covid-19. In narrative research, the inquiries that tell their stories are particular rather than representative of the population (Cohen, et al., 2001). Because the participant and the researcher are the same person, we do not use direct interview to avoid direct interaction with the researcher and participant related the data. For the validity, the researchers ensured as follows: 
1. The researchers uses peer discussion to gain the sensibility of the account (Cresswell, 2003:196)

2. After 'restorying' the stories of others, the researchers took them back to story owner in order to confirm accuracy (Elçi and Devran, 2017:40)

3. The researchers also used triangulation to help in gaining greater rigor and more in-depth understanding of the issues of phenomena in question (Given, et al., 2008:254)

\section{RESULT AND DISCUSSION}

The purpose of this research is to debrief and share the experiences in integrating a video as the media in teaching of phonology. A chosen video is a native speaker video that tells about the current issue. Besides the students learn about Phonology, with the video, they also learn and aware of the current issue. Here the students learn about the intonation, pronunciation, and phonological rules of the words and sentence.

Because of a Corona pandemic situation, the learning should be e-learning in the process of teaching. The students started with the understanding of the material that lecturer has delivered about phonology. It needed little time to deliver the material, but they should spend much more time in discussion session. The lecturer delivered the references that should be read to the students through Google classroom. The next meeting, the lecturer used zoom application to explain about the material. Here, the lecturer gave the discussion session for a week through Google classroom. The lecturer would give the confirmation in the last day of the discussion week. If a meeting was needed to give the direct confirmation, the lecturer used zoom meeting application.

That technique was done in 6 meetings. The first meeting was for the introduction using zoom meeting application. The second meeting was for delivering the material. The next day after delivering the material was a discussion session that needed one week. The last day of a discussion session, the third meeting, the lecturer gave the confirmation through the Google classroom or zoom 
meeting application. The next material came to the fourth meeting. The discussion session belonged to the day after for one week.

The practice session came for the next of mid-semester. The lecturer gave instruction to the students to listen, analyze, write/transcript, and repeat the native speaker said in a video that was shared before. The first was the students asked to listen carefully. The second time, the students should analyze the intonation, pronunciation, and phonological rules of the words and sentence. It spent much more time because they should play back many times. Besides that, the students were also asked to transcript or write what they were hearing from the video. In the process of transcription, Bahasa subtitle helped them. Here, the lecturer guided the students in every step. From the guidance the lecturer got the data of the problems that the students faced. The lecturer categorized to four problems that students were faced. The problems were presented in the table below. The students felt:

\begin{tabular}{|l|l|} 
No. & The Problems \\
\hline 1. & The native speaker in the video speaks too fast. \\
\hline 2. & The pronunciation is unclear, so it is difficult to catch every single word. \\
\hline 3. & There are some new words or terms, so that it is difficult to understand the meaning. \\
\hline 4. & It is difficult to imitate the intonation and stressing of a word and sentence.
\end{tabular}

Table 1. The Problems of the Students Faced

From the table above it can be concluded that the students felt challenging to follow the native speaker because they cannot catch up words and phrase uttered by the natives in the video. The students considered that the sounds were unclear due to the connected speech of natives. Also, the students assumed that the native speaker used some new words or terms. The students had to check the dictionary to confirm what they listened. It caused the students often misunderstanding the information that the speaker delivered. Moreover, the students felt that they were less accustomed to listening to the supra-segmental features of sounds such as stress, length, pitch, and intonation of word, phrase, or sentences made by a native speaker. Therefore, they found difficulty to imitate the utterances of native speakers in the video. 
The last step of a practice session was rewinding the video by reading their transcription or directly repeated the native speaker in the video. The students submitted the task to the lecturer that would be scored through the audio or video recording platform. The scoring process was based on the accuracy and the appropriateness with the original video. Despite all the challenges, the lecturer observed that the students had done the test well.

\section{CONCLUSION AND SUGGESTION}

\section{Conclusion}

1. There are some advantages of using this way; (1) the first is that the video is easy accessible; (2) the second one is that the video also is appropriate with the current issue so the students, beside learn about phonology, also aware of the current issue; (3) the other one is the students can learn and practice whenever with (out) the guidance of the lecturer; (4) the last advantage that we can offer is the students can listen the native speaker easily because they can play back the video anytime when they cannot catch the word or meaning.

2. The problems that students face in using of a video as the teaching media in Phonology arise in four categories. The students felt that the native speaker spook too fast. Besides that, they also felt that the pronunciation was not clear, so that it made difficult to catch every single word. The next problem is that there were some new terms. The final problem that students face is that they were difficult to imitate the video, especially on the intonation and stressing of a word or a sentence. 


\section{Suggestion}

There are many teaching techniques that can be applied in teaching of phonology. Even more, there are many teaching medium that can be used in teaching of phonology. Although, it is difficult to say that one technique and media are the best way in teaching of phonology. We suggest that: (1) Teacher should adjust with the situation and condition of the field. Here we try to confirm that this technique and media are appropriate with the situation and condition; (2) it needs the depth-inquiry about the effect of the media in teaching of phonology, teaching techniques can be applied in the media so the next researcher can extend this research; (4) it can be different result to the other research based on the situation and condition of the field.

\section{REFERENCES}

Budiman, A. (2017). Behaviorism and Foreign Language Teaching Methodology. Bengkulu: English Franca.

Carson, L. (2004). Relatedness and learner autonomy: A case study of an adult refugee learning in English in Ireland. Dublin: Trinity's Access to Research Achieve.

Corder, P.S. (1968). Advanced Study and the Experienced Teacher. Cambridge: Cambridge University Press.

Cresswell, J. W. (2003). Research Design: Qualitative, Quantitative and Mixed Methods Approaches. Sage Publication: Thousand Oaks.

Crystal, D. (1997). The Cambridge encyclopedia of the English language. Cambridge: Cambridge University Press.

Dawson, Hope C. and Phelan, Michel (ed.) (2016) Language Files 12ed. Columbus: The Ohio University Press.

Elçi, Alev and Devran, Çubukçuoğlu. 2014. A Narrative Research Approach: The Experiences of Social Media Support in Higher Education. P. Zaphiris (Eds.): Human-Computer Interaction, Part I. 36-42.

Fauziati, E. (2016). Applied Linguistics: Principles of Foreign Language Teaching, Learning, and Researching. Surakarta: Era Pustaka Utama. 
Handayani, Dyah Indri Fitri. 2017. Teaching English Pronunciation Using Film. Journal of English and Educatio,. Vol 5 No 2. 194-201.

Kanno, Yasuko and Varghese, Manka M. 2010. 'Immigrant and Refugee ESL Students' Challenges to Accessing Four-Year College Education: From Language Policy to Educational Policy', Journal of Language, Identity \& Education.

Kentjono, Joko. (1990). Dasar-Dasar Linguistik Umum. Jakarta: Fakultas Sastra Universitas Indonesia.Kumaravadivelu, B. (2006) Understanding Language Teaching: from Method to Postmethod. New Jersey: Lawrence Erlbaum Associates Publishers.

Kurniasih. (2011) Teaching the Four Language Skills in Primary EFL Classroom: Some Considerations. Jakarta: Journal of English Teaching.

Lanteigne, B. (2006). Common, Persistent Errors in English by Brazilian Portuguese Speakers. Lithuania: TEFL Web Journal.

Lauder, A. (2008). The Status and Function of English in Indonesia: A Review of Key Factors. Depok: Department of Linguistics, FIB, University of Indonesia. Matsuda, S. (2004). A Longitudinal Diary Study on Orientations of University EFL Learners in Japan. Kyoto: Doshisa Studies in Language and Culture.

Mellisa, M., \& Yanda, Y. D. (2019). Developing Audio-visual Learning Media Based on Video Documentary on Tissue Culture Explant of Dendrobium Bigibbum. Malang: Jurnal Pendidikan Biologi Indonesia.

Odden, D. (2006). Introducing Phonology. Cambridge: Cambridge University Press.

Pargente, R. (2015). Reflections of Students on Their English Language Learning Experiences. Misamis Oriental: Misamis Oriental State College of Agriculture and Technology.

Putri, R. G., Titin, T., \& Santoso, R. (2019). Film Dokumenter Pemanfaatan Tumbuhan Berkhasiat Obat sebagai Media Pembelajaran Materi Sistem Pencernaan. Banda Aceh: Indonesian Journal of Science Education.

Pyrkova, Kseniya V., and Ryabova, Tatyana. 2016. Imitation Methods in Teaching Decision-Making to Students of Medical Faculties. IEJME-Mathematic Education, Vol. 11 No 4. 539-548. 
Ramelan. (2003). English Phonetics. Semarang: UNNES Press.

Shabarinath, C., \& Dasaradhi, K. (n.d.). Importance of Linguistics in English Language. Nagpur: International Journal of English Languages, Literatures and Humanities.

Simatupang, M. (1999). Bahasa Inggris: Variasi Yang Mana? Suatu Tinjauan Ulang Tentang Status Bahasa Inggris di Indonesia. Jakarta: Pusat Kajian dan Budaya Unika Atma Jaya.

Skinner, B. F. (1976). About Behaviorism. New York: Vintage Books.

Tiono, N. I., \& Yosta, A. M. (2008). A Study Of English Phonological Errors Produced By English Department Students. Surabaya: k@ta.

Wilkins, D.A. (1972). Linguistics in Language Teaching. London: Edward Arnold.

University of Sheffield (2012) Why Study Phonology? Retrieved from: https://sites.google.com/a/sheffield.ac.uk/aal2013/branches/phonology/whystudy-phonology. 